\title{
Accessibility for All, Becak Drivers in Jakarta Since $1988^{*}$
}

\author{
Yoshifumi Azuma \\ Ritsumeikan University, Kyoto, Japan
}

\begin{abstract}
The Becak (a manpowered tricycle taxi) was exported to major Indonesian cities via China from Yokohama in the 1930s. During the mid-20th century they spread throughout the major cities of Asia, and came to be used as a vehicle for daily use. However, since the 1970s, growing traffic congestion caused by an increase in the number of motorcycles and cars, has pushed the becak into the back streets of cities. In the case of Indonesia, government came to strictly prohibit them through the perception that they were a symbol of backwardness and they have gradually disappeared from the city. This culture of viewing becak as a symbol of backwardness has remained ingrained over the decades. In Jakarta, they were banned from use in lanes and back-alleys to finally disappear from public view through a brutal clearance method known as 'becak hunting' (crackdowns) in 1992. However, they re-emerged on Jakarta's streets during the chaos after Suharto's resignation in 1998. Governor Sutiyoso at the time banned them anew, yet democratic transformation through the rise of civil society did not tolerate subsequent crackdowns As of 2016, hundreds of becak vehicles now plow the streets of Jakarta, mainly concentrated in back-alley neighbourhoods. Based on primary data sources gathered over a 30-year period (1989, 1998, and 2011-2015), this paper examines socio-economic transformation and continuity and investigates the extent in which the changing political economy of Jakarta affects drivers' accessibility. Furthermore, the paper forecasts the survival strategies of becak drivers under ungoing policy changes and the positions of previous and present Governors.
\end{abstract}

Keywords: accessibility, beca or becak, Jakarta, urban poor, migration

\section{Introduction}

Ben Anderson (1936-2015), who recently passed away during a field study in East Java, argued over recent development in Djakarta. Although the term "accessibility" is used in disability studies, Anderson borrowed this notion to articulate the transformation of Jakarta.

I will talk about accessibility in various contexts in post-revolutionary Djakarta. All streets were open to betjaks (tri-cycles) and bicycles, even occasionally a kuda (horse) or two. Access to districts and there were no gated communities. Access to public spaces: near naked boys playing soccer opposite Hotel Indonesia; access to Presidential Palace for wayang performances; access to politicians; access to universities and schools; access to prostitutes, since they were not yet sequestered. Street culture, children outside houses most of the time, not inside - linguistic access: everyday bahasa Indonesia without levels of deference. (Anderson, Lecture held at Kyoto on Thursday, Nov. 12, 2009)

Until their disappearance in 1992, the becak not only figured as a feature of Jakarta's tourist fabric, but

\footnotetext{
* This paper was based on a presentation given at the "2016 Annual Conference of Southeast Asian Studies in Taiwan" held 2016 September 22-23 at National Cengchi University. The author expresses his gratitude to the Fukutake Foundation, Tokyo, Japan, for generous support that funded field surveys between 2010-2015.

Yoshifumi Azuma, Ph.D., Professor, College of Policy Science, Ritsumeikan University, Kyoto, Japan.
} 
also played an important role as a popular form of public transport for the lower and lower-middle class people. Almost all tour guidebooks on Indonesia contain illustrations of becak and directions on how to use them. In 1992, all were banned from use on lanes and back-alleys in Jakarta and finally disappeared through the use of Garokan (a brutal crackdown method known as becak hunting). However, they re-emerged on the streets of Jakarta post-1998 after Suharto's resignation. At the time, the then Governor Sutiyoso, banned them anew, yet democratic transformation through the rise of civil society did not tolerate renewed crackdowns (Azuma, 2006). As of 2018, hundreds of becak vehicles plow the streets of Jakarta, mainly concentrated in back-alley neighbourhoods areas. Based on primary data sources gathered in 1988, 1998 and during 2011-2015, this paper examines socio-economic transformation and continuity and investigates the extent in which the changing political economy of Jakarta affects drivers' accessibility.

In 2009, when the renowned scholar of southeast Asia, Ben Anderson commented on post-war Jakarta becak were operating all over Jakarta, and their accessibility was open to all classes (Anderson, 2010, p. 114). Anderson held a negative image of the New Order regime; in part because only a limited number of people during the period of the New Order had accessibility to everything. To contextualizae this observation, this paper examines four types of accessibility in order to examine the extent in which becak drivers have accessibility to socio-economic benefits in Jakarta.

\section{Access to Job Opportunities}

Job opportunities for rural-urban migrants, mostly less educated farmers, are severely limited. In searching for employment, networks play a crucial role. Asking friends or kin makes searching for work much more comfortable in the informal sector. Even the necessary tools for the trade business (becak and food-stalls) were leased through networks.

\section{Access to Shelter}

There is a widely held stereotype that after migrant farmers first visit Jakarta, they can't find work nor shelter. However, this is not precise. In the past, only a limited number of villages, those which have stable networks through friends, kin, and acquaintances, could migrate to Jakarta (Azuma, 2001b). However, after the Suharto regime collapsed, mostly illegal squatters moved into the poor residential areas of Jakarta, which expanded to provide affordable low-cost (and unlawful) shelters for becak drivers (Winayanti \& Lang, 2004).

\section{Access to the Education}

In Jakarta, there exists a significant gap in educational attainment between the rich and the poor. Migrant farmers have little access to affordable public school due to the fact that a Jakarta residential card is necessary to access the public education system (Jones, Rangkuti, Utomo, \& McDonald, 2016).

\section{Access to Arable Land}

The World Bank (2007) has argued that agricultural development in Indonesia is undergoing transformation. It can be said that a "pattern was observed in Indonesia where the emergence of rural towns ("urbanization without migration") was further emphasized" (World Bank, 2007, p. 36). In order to escape from poverty, the Indonesian agricultural sector adopted entrepreneurship, the development of non-agricultural industries, and migration to urban areas. Becak drivers opted to migrate to Jakarta, and their arable land was either sold to market-oriented farmers or transformed into industrial sites. Consequently, arable land area owned by less dynamic migrant farmers declined or became occupied by a limited number of landlords. This tendency is pronounced among becak drivers. 
The structure of this paper is as follows. After verifying the significance of Anderson's accessibility hypothesis through empirical data, the next section offers an analytical overview of the history and geographical distribution of becak in 1988, 1998, 2010-2011, and 2014-2015, with special focus on the period since 1998 immediately following the end of Soeharto regime. First, since the 1970s, becak operation areas gradually diminished across Jakarta to become limited to the northern part of the city, and finally reduced to nine operating areas. Second, a comparative examination of data collected from surveys conducted in 1988-1989, 1998, 2010-2011, and 2014-2015 is presented. This is done to show the degree in which structural change overshadows and determines the nature of becak vehicles' operations, including in business areas. In other words, how does the changing socio-economic and demographic background contribute to the further marginalization of human-powered urban transport methods?

This paper also clarifies that accessibility to the job market, education, shelter, and arable land have all been severely limited. As a result of limited operation areas and frequent flooding in the north of Jakarta, working conditions for elderly drivers have become lax. Nonetheless, becak driving is no longer the harsh physical job that it was in the past. Demographic data shows the rapid aging of drivers, and this underlies the limited accessibly to work, education, shelter, and arable land.

The New Order's lack of accessibility, as noted by Ben Anderson, does not always sound precise in the context of this micro level survey. Harsh regulations for becak as well as the confiscation of becak vehicles by the New Order is evident. Yet, due to restricted becak operation areas, driving does not require more physical toughness; even the elderly have had access to and participated in this physical job. This is, in a way, the irony of history. In the past, the transition of authority was always unpredictable. And a historic move stemming from the collapse of Suharto's development regime through to democratization is a process in progress. While convergence has been gradual, socio-economic changes that becak experience contribute to promote a better understanding of the urban poor in contemporary Jakarta.

\section{A Brief History of Becak Transport in Jakarta}

Archival records show that some becak vehicles were exported to China from Yokohama in the 1920s, and then spread throughout southeast Asia (Kompas, 7, March 2016). In Jakarta during the 1960s, becak vehicles were known as the "King of the streets," despite a ban policy instituted in the 1970s and 1980s. Yet, in 1992 all becak were banned throughout Jakarta and finally disappeared. However, they started to re-emerge after Suharto's resignation in 1998. As briefly mentioned in the previous section, at the time, the then Governor Sutiyoso banned them again, yet democratic transformation in Indonesia and the rise of civil society did not tolerate this policy (Azuma, 2001a). Nowadays hundreds of becak vehicles are working as before in the back streets of Jakarta, mainly concentrated in residential areas. The question that arises from repeated field surveys is to what degree does globalization overshadow and determine the nature of becak vehicles' operation, including in business areas? To situate this question there is a need to re-examine becak vehicles' operation areas. In 1988-1989, they operated throughout all regions in Jakarta, including upmarket southern suburbs. After their resurgence in 1998, their operation areas were still in five districts across Jakarta.

However, harsh becak persecutions posed a significant threat to drivers, pushing them into specific territories between 2011-2012 when the Jakarta municipal Government banned them yet again and removed becak from the cityscape. However, the situation from the early 2010s was more stable than before and the likelihood of a continuation of the practice of confiscation was lower than previous periods where ban policies 
were in put into place (Azuma, 2001a). On $20^{\text {th }}$ September 2012, Jakarta provincial elections were held in which the Mayor of Solo (Surakarta) Joko Widodo (Jokowi) challenged Fauji Bowo and won with an overwhelming victory. With a pro-urban poor policy, he stood by becak, and as a result of this more pro-poor policies were expected. In fact, many authoritarian bureaucrats in government lost their power base. However, Basuki Cahaya Purnama (know as Ahok), an Indonesian of ethnic Chinese origin who was promoted from vice-governor following the inauguration of Jokowi as a President, was different ${ }^{1}$. In 2017, after a chaotic governmental election, the newly elected governor Anise Buswaden was inaugurated. Subsequently, he changed the policy towards becak to remove the Becak prohibition Law (Perda 2007, Nomor 8) in line with his campaign slogan "Development without fear/pain."

\section{Geographic Distribution of Becak}

In 1988-1989, becak operated throughout most regions in Jakarta, including the upland southern suburbs. After a resurgence in use in 1998, operation areas were still spread out across the city. However, a harsh crackdown posed a significant threat to becak vehicles, which pushed them into specific territories in 2011-2012, 2015-2016. The Jakarta municipal government banned them again and removed becak from the city. However, frequent flooding (kebanjiran) over the year caused by land subsidence due to the over-exploitation of groundwater as well as the rise in Jakarta bay's sea level came to present a large problem. Climate change does determine their operation areas due to the severe flooding that occurs. Becak riding businesses around the slums have to contend with frequent flooding that leads to high levels of congestion. Clearly, becak operations areas sit parallel to kebanjiran territories. The demand in submerged areas due to serious subsidence from pumping groundwater from the northern part of Jakarta plays a crucial role. Additionally, the rise of sea levels as a result of global warming have led to the expansion of submerged areas. Thunderclouds with heavy precipitation occur even in the dry season due to climate change and in turn accelerate submergence. The above-mentioned environmental factor, as well as a total ban policy on becak forms a determinant factor in vehicles' operation areas. In other words, the greater the expansion of submergence areas, the greater the need for becak transportation. In this sense, democratization and submergence have contributed to developing accessibility for becak drivers (Garschagen, Surtiari, \& Harb, 2018).

In the early 1990s, the main business districts were Hayam Wuruk, Mangga Besar, Teluk Gong, Rawamangun, Priok, Pasar Enjo, Jembatan Lima, Kramat Tunggak, Ampera, and Kebun Kacang with a wide range from north to east Jakarta (See Figure 1). However, becak operation areas were displaced due to the intensified crackdowns under Governor Sutiyoso. This is due to the fact that to avoid unnecessary conflicts with 'public order enforcers' (Satuan Polisi Pamong Praja SATPOL-PP), becak drivers moved to north Jakarta. In 1998, central Jakarta was one of the major operational areas this later shifted to the north of the city. In this regard becak areas were reduced and accessibility became limited.

\footnotetext{
${ }^{1}$ Setengah Abad Kontroversi Becak di Jakarta (A controversial half century of becak drivers in Jakarta), Kompas, 7 March 2016.
} 
Map of research pedicab in Jakarta, 1998

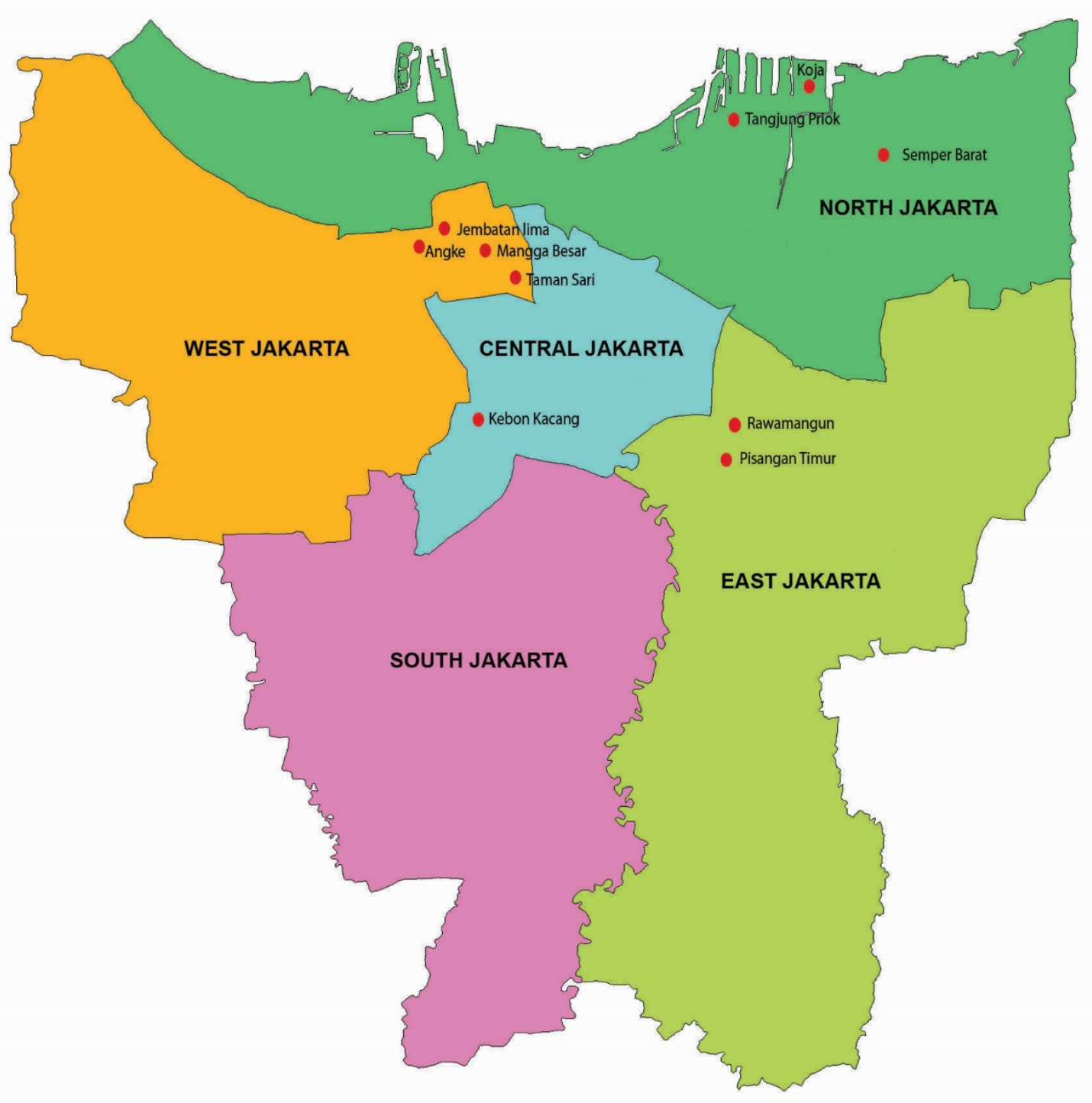

Figure 1. Map of research area in Jakarta, 1998. Sources: Field Study, 1998.

Figure 1 shows the operation area of becak drivers in 1998. Becak vehicles operated in traditional markets and entertainment areas close to densely populated residential areas all over the city and were known as "kings of the street" (Jellinek, 1991). Yet, comparisons between 1998 and 2010-2012 surveys indicate that becak operation areas in 1998 were more ubiquitous in terms of accessibility ${ }^{2}$. However, there is no accessibility to the areas that expected a demand from many passengers such as traditional markets (Pasar) and bus terminals. However, the implementation of the becak ban policy by Perda No. 11/1988 saved face for Governor Sutiyoso. 2007 was his final year in office and harsh operations developed into a clash with SATPOL-PP through stone throwing in Sunen District ${ }^{3}$. As a result, the head of Sunen District, Pak Camat, expressed that becak operations

\footnotetext{
2 Regarding the Governor Sutiyoso's sudden policy change since 1998, see Azuma (2001a; 2001b).

${ }^{3}$ Media Indonesia, 2007.03.03.
} 
must be banned by the end of 2007 and this was authorized by Perda No. 8, pasal 29 (DKI, 2007, p. 9) ${ }^{4}$.

Nonetheless, growing democratization pressured Pak Camat to collude with becak operations in the district. Mr. Moftar, a representative of the Union of Becak (Sebaja), which was established with funding from the Urban Poor Consortium (UPC) with over 150 members, organized a demonstration in Pademagan District and they gathered at the Camat Office ${ }^{5}$. Becak drivers had requested a safe and free operation in some specific areas of Jakarta. However, Governor Sutiyoso rejected this request on the legal basis of PELDA No. 11/1988, and stubbornly tried to eliminate becak. Sutiyoso employed authoritarian methods through SATPOL-PP. Therefore, after 2010-2011 becak were gradually relegated to flooded and salt damaged areas in the northern district area. In this context, accessibility to all areas in Jakarta became limited.

Figure 2 shows the becak business district in the 2011-2012 survey. Becak had limited accessibility to Jakarta, and the red dots indicates the operation points in some flooded (submerged) areas in the northern district area.

Under democratization, NGOs, especially UPC, contributed to awakening drivers sense of entitlement. UPC in Padamangan district of north Jakarta provided a fund for Sebaja to condemn crackdowns to the deputy head of Pademangan District, and demonstrations would be organized if these were carried out. ${ }^{6}$

\footnotetext{
${ }^{4}$ Different from the 1998 survey, the operation areas in 2010-2011 and 2014-2015 were north and west flooding areas, excluding Tanah Tinggi. Regarding the rationale behind why becak vehicles survived in mainly flooding areas, an additional survey from the user side is necessary and discussions concerning this are beyond the remit of this paper.

${ }_{5}$ Tukang becak Demo Tagih Janji Wakil Camat (Becak drivers demonstrate to keep the promise of the Deputy District Head), Republika, 16.08.2005.

6 Tukang becak Demo Tagih Janji Wakil Camat, (Becak drivers demonstrate to keep the promise of the Deputy District Head) Republika, 16.08.2005.
} 
Map of research pedicab in Jakarta, 2011/2012

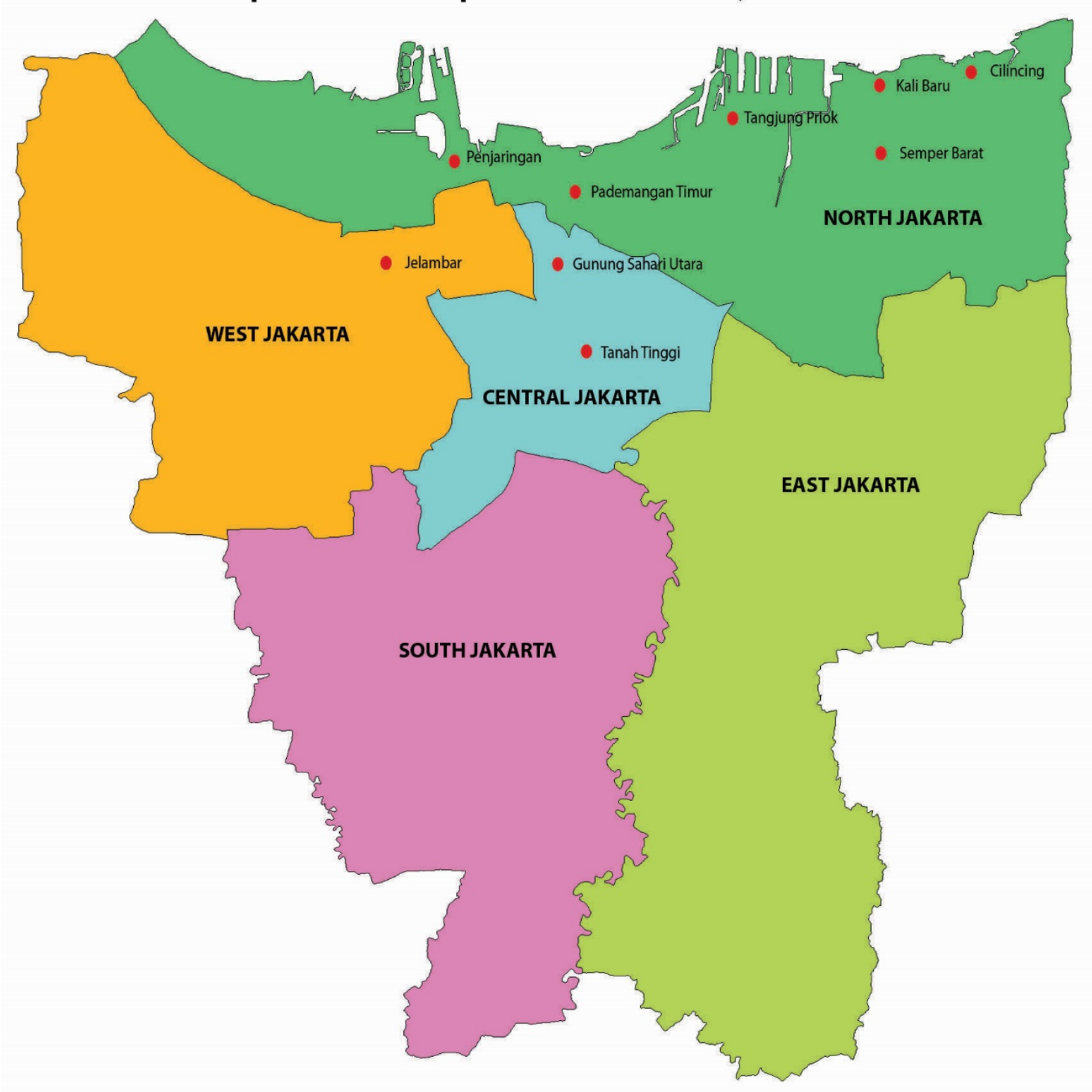

Figure 2. Map of research area in Jakarta, 2011-2012. Sources: Field Study, 2011-2012. 


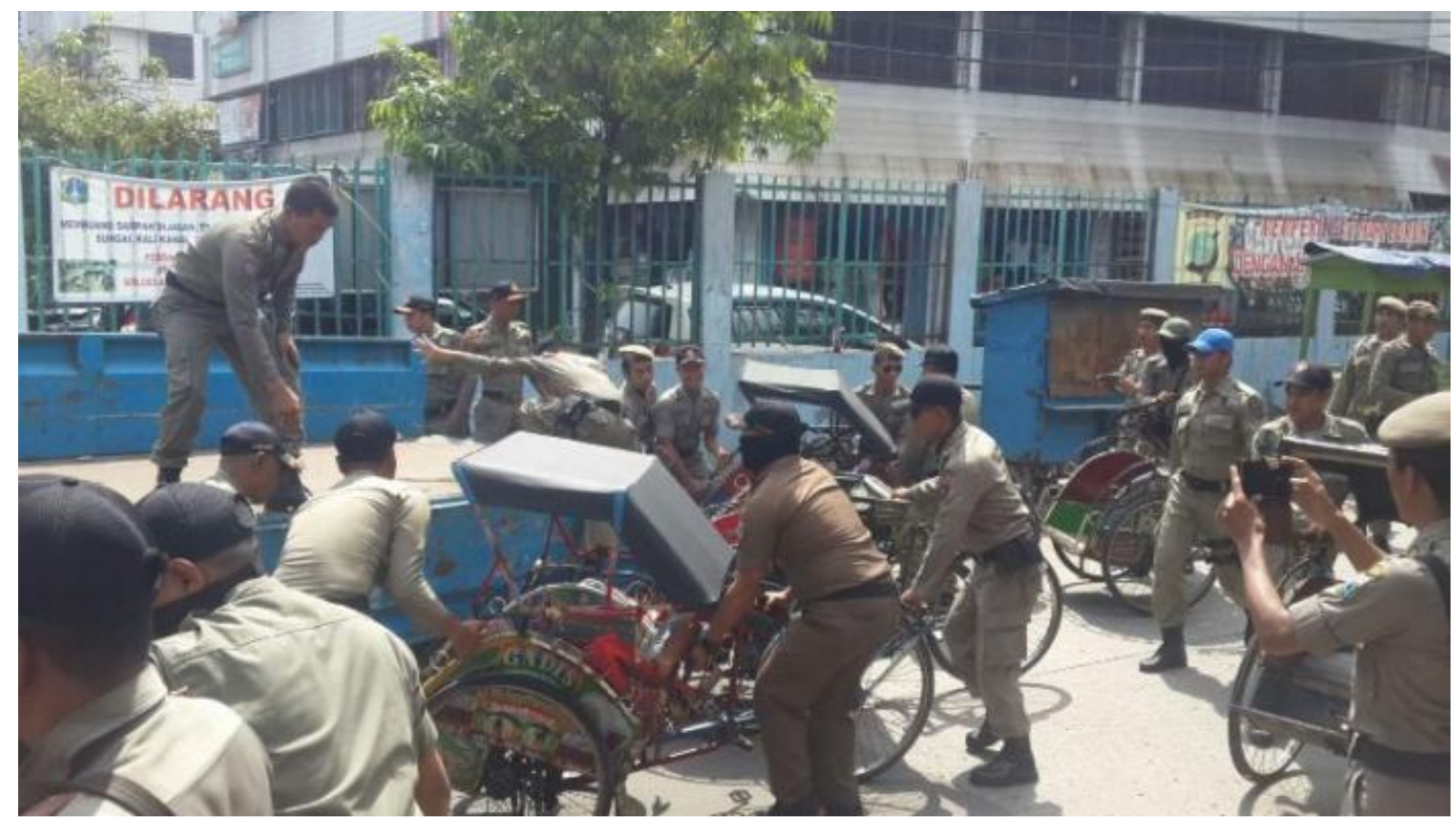

Figure 3. Garokan, Tribune Jakarta, 2015.12.20.

In 2007, Sutiyoso handed over the governor's post to his deputy, Fauji Bowo. Under the next Governor, becak vehicles and SATPOL-PP co-existed without any conflict. For example, the boundary of a main street in Pademangan, district office, was divided into a becak permit zone and becak free zone ${ }^{7}$. State authority also admitted that an important target of crackdowns was street vendors (Kakilima) thus under the governor Fauji Bowo these became nominal. Unlike under the term of Sutiyoso and Wiyogo the budget for becak confiscation was limited and this resulted in relatively safety for becak drivers (Azuma, 2003). Furthermore, since Governor Fauji was less cautious, some Sebaja members were strengthened through the governor's apathy and expressed support for his second term in the June 2012 election.

It should be noted here that improving civil servants' salary under the President Yudhoyono administration had a strong impact on the incentive (Semagat) of SATPOL-PP. Salaries were raised, but valuable honorarium payments (Honor) were reduced or abolished. For example, a famous becak graveyard is located in Cakung, Cilincing of north Jakarta, but the budget allocated to run this facility was drastically reduced. ${ }^{8}$ Payments (as honorariums), when used, contributed more in total terms. Under Governor Wiyogo, if a becak vehicle was confiscated, an honorarium (Rp 30,000-50,000) was paid, but now such incentives no longer exist. In this context, Yudhoyono's reform contributed to a slowdown of the confiscation of becak. Subsequently, it revived bad habits: to sell a confiscated becak vehicle used to be common practice, but now this is more apparent among SATPOL-PP officials. ${ }^{9}$

\footnotetext{
${ }^{7}$ Interview with Mr. Bambang, the head of north Jakarta SATPOL-PP at Cakung on 9th March 2011.

${ }^{8}$ Monthly salary was Rp 2.2 million plus Rp 4.4 million allowances (Tunjangan) which amounted to Rp 6.6 million.

9 Becak Hasil Razia Dijual Oknum, (Becak raid results for sale,) Pos Kota, 30 Juli 2009. The price for becak vehicles varies from Rp 300,000 to Rp 500,000 depending on their condition.
} 


\section{Empirical Data Analyses}

\section{Access to Job Opportunities}

The demographics of becak drivers have changed substantially. Table 1 shows a breakdown of respondent ages since the 1988-1989 survey. The most productive and active age group (25-39) made up a significant proportion (close to two-thirds) until the 1998 survey. However, in 2010-2011, this age group (25-39) declined to $28 \%$ (almost one-third) then rose slightly to $30.2 \%$ in $2014-2015$. There is need to be cautious about the growing proportion of those over 50 as well as the declining proportion of those less than 24 years old. It seems that the age structure has significantly changed for those aged over 27. If we compare to Jakarta's male population aged over 15 in the Special Region of Jakarka (Daerah Istimewa Jakarta DKI) data for 2008 as well as the 2015 Sekernas DKI, it becomes apparent that the becak driver population is ageing.

Table 1

Age Distribution of Becak Drivers and DKI Male Age Over 15, According to Age and Survey Year (\%)

\begin{tabular}{lllllll}
\hline Age/year & $1988-1989$ & 1998 & $2010-2011$ & $\begin{array}{l}\text { 2008 DKI male } \\
\text { age over 15 }\end{array}$ & 2014-2015 & $\begin{array}{l}\text { Sakernas DKI } \\
\text { male 2015 }\end{array}$ \\
\hline $15-24$ & 21.9 & 15.0 & 4.0 & 22.2 & 0 & 54.3 \\
$25-29$ & 19.2 & 17.2 & 6.8 & 14.4 & 5.7 & 18.0 \\
$30-34$ & 22.1 & 19.4 & 9.6 & 15.8 & 13.2 & 9.1 \\
$35-39$ & 11.5 & 17.2 & 11.6 & 12.9 & 11.3 & 5.3 \\
$40-44$ & 9.6 & 12.8 & 15.9 & 9.6 & 9.4 & 3.1 \\
$45-49$ & 8.7 & 4.8 & 15.1 & 7.5 & 11.3 & 3.5 \\
$50+$ & 7.9 & 13.6 & 37.0 & 17.6 & 49.1 & 6.8 \\
Total & $100 \%$ & $100 \%$ & $100 \%$ & $100 \%$ & $100 \%$ & $100 \%$ \\
(\#) & $(312)$ & $(274)$ & $(251)$ & $(3,378,001)$ & $(53)$ & $(4,487,241)$ \\
\hline
\end{tabular}

Note. Sources: Field Studies, 1998, 2010-2011, 2014-2015; DKI and Sakernas, 2016; Azuma, 2003.

Why is such a change so evident? Figures 2 and 3 suggest an answer to this question. Restrictive policies for becak transport since the mid-1960s by DKI municipal government can be identified as the primary cause of this phenomenon. In the 1998 survey, the operations area of becak transport covered almost all areas of Jakarta, and to drive a becak in larger operation areas required a more powerful, muscular body for riding. However, since the stricter policy was established in 2007 by Perda No. 8, pasal 29 (Kantoru Statistik DKI, 2007, p. 9), operation areas became limited enclaves in mainly northern Jakarta, which can be characterized as flat land, and this contributed to more comfortable riding conditions. Hence, becak driving is no longer a physically tough and difficult occupation - if anything even older adults can access it, and this contributes to the elderly being able to secure a daily subsistence income.

In this context, the government policy for Becak has a significant effect on accessibility to becak work. Becak driving areas have become restricted to narrow and flat regions. Table 1 shows the changing age distribution between 1988-2015. In the 1998 survey, the average age was 34.6 years old with the youngest at 15, and the oldest at 75. However, in 2010-2011, the average age was 44.3 years old the youngest was 19 , and the oldest was 78 in the 2014-2015 surveys respectively. If the respondents in the 1998 survey still drove becak the same way in 2010-2011, the average age should have increased by about 10 years. However, Table 2 shows that $60.2 \%$ have not ridden. Furthermore, drivers aged no more than 55 years old used to ride becak in Jakarta. 
Table 2

Previous Experience of Becak Riding in 1998, 2010-2011, and 2014-2015 (\%)

\begin{tabular}{llll}
\hline Used to ride becak & 1998 & $2010-2011$ & $2014-2015$ \\
\hline Yes & 53.1 & 39.8 & 69.8 \\
No & 46.9 & 60.2 & 30.2 \\
Total & $100 \%$ & $100 \%$ & $100 \%$ \\
$(\#)$ & $(275)$ & $(251)$ & $(53)$ \\
\hline
\end{tabular}

Note. Sources: Field Studies, 1998, 2010-2011, and 2014-2015; Azuma, 2003.

When looking at others in the age group, those who never rode becak are the majority and for the elderly, becak driving is easier to access than other occupations. In this context, becak is the easiest work across all age groups. This is because Perda No. 8, pasal 29 (DKI, 2007, p. 9) made operation areas limited enclaves in mainly northern Jakarta, which can be characterized as a flat area. This has, as mentioned above, contributed to more comfortable riding conditions.

In the 1980s, Jellinek (1992) and Azuma (2001a; 2001b; 2003) noted a phenomenon in which the profession from the particular origin (chain migration and chain occupation) was evident. Table 3 shows that since 1998, nearly half of the respondents became drivers, and in 2010-2011 this increased to more than half (62.9\%), and finally more than $80 \%$ of respondents got into becak riding within a week in 2014-2015. Hence, it can be said that becak driving is an immediately accessible occupation. Even if there is no money, becak driving can be accessed as long as drivers are in reasonably good health and as such it is possible to obtain cash income from the first day in Jakarta. For example, to conduct business in the wheeled stalls (Kakilima) some primary funds are needed to buy both stalls and food.

Table 3

Number of Days Required to obtain Work in Jakarta (\%)

\begin{tabular}{llll}
\hline The number of days needed & 1998 & $2010-2011$ & $2014-2015$ \\
\hline 1-3 days & 30.2 & 42.2 & 77.4 \\
4-7 days & 13.8 & 20.7 & 5.7 \\
8-14 days & 1.8 & 4.4 & - \\
15-30 days & 0.7 & 8.4 & 13.2 \\
1 month & 6.5 & 24.3 & - \\
More than 1 month & 47.0 & - & $100 \%$ \\
Total & $100 \%$ & $100 \%$ & $(53)$ \\
$($ \#) & $(275)$ & $(251)$ & \\
\hline
\end{tabular}

Note. Sources: Field Studies, 1998, 2010-2011, and 2014-2015; Azuma, 2003.

The next question to ask is why can becak drivers obtain access to becak within 1-3 days. As many researchers working on the informal sector in Jakarta (Azuma, 2001a; Jellinek, 1992) have shown, the connection to job hunting is evident. Table 4 shows those who came together with friends reduced slightly by each year, and those who came with their fathers and relatives are increasing. Those coming alone have not shown a substantial change. We can say that accessibility was reduced in the sense that it relies on relatives rather than friends. 
Table 4

First Time to Jakarta with another person, (\%)

\begin{tabular}{llll}
\hline First to Jakarta with & 1998 & $2010-2011$ & $2014-2015$ \\
\hline Friend & 50.0 & 36.9 & 34.0 \\
Brother & 18.0 & 19.5 & 24.5 \\
Kin & 6.7 & 14.9 & 9.4 \\
Father & 1.3 & 9.1 & 3.8 \\
Alone & 18.7 & 19.5 & 26.4 \\
Total & $100 \%$ & $100 \%$ & $100 \%$ \\
$(\#)$ & $(142)$ & $(241)$ & $(52)$ \\
\hline
\end{tabular}

Note. Sources: Field Studies, 1998, 2010-2011, and 2014-2015; Azuma, 2003.

\section{Access to Shelter}

Becak driving as an income-earning activity has been dominated by migrant farmers from the rural west and central Java. From the north coast of the rural west and central Java, migrants first arrive in Jakarta with a fully occupied old bus. Small rooms known as Pondoks are their first shelters in Jakarta. Table 5 shows the type of accommodation available when I first came to Jakarta. Noteworthy changes are a reduction of "friends' room," and a sharp increase in the number of "with family's home" which is in line with the findings by Qibthiyyah and Utomo (2016). Those who sleep on the becak have also increased (Azuma, 1994; 2000).

Table 5

In Response to the Question: The First Time to Jakarta, Where Did You Stay? (\%)

\begin{tabular}{llll}
\hline First accommodation & 1998 & $2010-2011$ & $2014-2015$ \\
\hline Pondok & 24.7 & 16.3 & 30.2 \\
Kontrakan & 6.0 & 26.3 & 18.9 \\
Friends' room & 32.7 & 8.4 & 5.7 \\
With family's home & 19.3 & 23.1 & 24.5 \\
On becak & 5.3 & 6.0 & 18.9 \\
Own house & 2.0 & 2.0 & 0 \\
On street & 2.0 & 1.2 & 0 \\
Others & 4.0 & 16.7 & 1.9 \\
Total & $100 \%$ & $100 \%$ & $100 \%$ \\
$(\#)$ & $(267)$ & $(251)$ & $(53)$ \\
\hline
\end{tabular}

Note. Sources: Field Studies, 1998, 2010-2011, and 2014-2015; Azuma, 2003.

A significant increase in Kontrakan (boarding room) is a mirror image decline of the rental fee as well as an increase in the number of cheap rent rooms in Jakarta. Table 5 shows that the proportion of Pondok with Tauke (Boss) ${ }^{10}$ decreased from $24.7 \%$ in 1998 to $13.5 \%$ in $2011-2012$, and then jumped to $30.2 \%$ in 2014-2015. The so-called Kontrakan, which is the rental of a small room, was negligible in 1998. However, in 2010, the proportion increased to more than a quarter (26.3\%). From this we can assume that the collapse of the Suharto regime made forced requisition difficult and squatters were able to expand and construct a hut without permission. According to Winayantia and Lang (2004), squatter residences were demolished by the government in Penas Tunggal, Jakarta. However, the democratization contributed to legitimatize their land titles, NGOs helped them to acquire Land Certificates, and began to improve their living environment.

${ }^{10}$ Regarding Tauke (頭家) or see Azuma, 2001. Tauke meaning boss comes originally from a Chinese dialect. 
In general, squatters continued to improve the living environment and this became an income source by renting space to some reliable people. Migrant workers coming into Jakarta also tended to stay in Kontrakan accomodation. If accommodation is not available at a Pondok, migrants are forced to live in Kontrakan. Only $20 \%$ of Kontrakan landlords shared the same prefecture, district, sub-district of a village. In addition, between 1988 and 2014-2015, the most significant difference was room-sharing which plummeted from $17.8 \%$ (1988) to $8.4 \%$ (2011-2012) and then to $5.7 \%$ (2014-2015).

This is due to the fact that ties based on the birthplace and neighborhood have become sparse and the relationship with Teman (generally neighbours and friends of the village) became weak. In 1998, 19.3\% still relied on kin families (23.1\% in 2011-2012 and $24.5 \%$ in 2014-2015) rather than friends. If kin are not around and cannot be relied upon, an alternative way was to stay in Kontrakan with strangers. In this context, accessibility to Kontrakan has improved. The expansion of human rights after Suharto's resignation also expanded the illegal living space of the poor. To this we must also take into account Kontrakan rents. In 2011-2012 and 2014-2015, the largest proportion of net income of becak driving per day was between Rp 30,000-39,999. In contrast, monthly room charge of Kontrakan accounted for more than $80 \%$ from Rp 50,000 to $\mathrm{Rp} 299,999$. Hence, if the drivers worked for more than seven days, it would be enough to secure accommodation.

In summary, access to shelter in Jakarta has improved since the fall of Suharto. In the 1998 survey, those who slept on becak accounted for one-quarter. In contrast, the proportion declined to 15 percent in 2010-2011. The category to sleep at home and Kontrakan accounted for more than half. Former President Suharto's daughter Tutut bought out the Pademangan district for new business after turmoil in the post-Suharto period. However, this area was illegally occupied by the urban poor, including becak drivers and state authorities were no longer able to evict them (Kegusuran Tanah) due to an increased awareness of human rights. Becak driving was once a typical circular migrant occupation, but improving access to Kontrakan in urban squatting changed their migration pattern. Nowadays, they live with their spouses and remit money to children in their home village (Qibthiyyah \& Utomo, 2016). This is also an increasing trend and compulsory acquisition of land by authorities (Gusuran Tanah) has become more crucial. In addition, the spread of mobile phones, as well as improved traffic for access, has boosted this new phenomenon. Nonetheless, declining community ties are also evident. For example, even when living in Kontrakan, they would prefer to rent Kontrakan from people who do not have a territorial relationship rather than rent a room from the same villagers. Such cases accounted for 113 of 144 (up to 78.5\%) respondents. Of course, an introduction from someone is a must, but there are no strict thresholds for newcomers. After Suharto stepped down, and in the context where Gusuran Tanah was not carried out frequently, there is a clear tendency for squatters to make money from Kontrakan as much as possible before official land evictions begin. This is common practice among illegal immigrants who were in Muara Baru. It can be said that the expansion of the illegal settlement area contributed to obtaining access to shelter in urban areas. However, on the other hand, a deterioration in security, such as that witnessed in Muara Baru was also evident (Winayantia \& Lang, 2004).

\section{Access to the Education}

Table 6 shows the changing patterns of educational attainment. What is notable is that there is a considerable gap between becak drivers' educational attainments and those in 2015 (Sekernas). Even in 2010-2011 and 2014-2015 more than half of the respondents did not complete primary school. Elderly becak 
drivers made up the larger proportion of this category, while by and large, a higher education level was apparent among youths. Even respondents with lower educational attainment can access becak driving work. Given the current high requirements (completed tertiary school) to obtain a job in the formal sector, it can be said that becak's accessibility is high for labourers with low educational attainment (Jones et al., 2016).

Table 6

Educational Attainment, According to the Year of the Survey, (\%)

\begin{tabular}{lllllll}
\hline $\begin{array}{l}\text { Researcher } \\
\text { (Year) }\end{array}$ & No school & $\begin{array}{l}\text { Primary school } \\
\text { unfinished }\end{array}$ & $\begin{array}{l}\text { Complete } \\
\text { P.S. }\end{array}$ & $\begin{array}{l}\text { Finish } \\
\text { JHS }\end{array}$ & +SHS & $\begin{array}{l}\text { Total } \\
(\#)\end{array}$ \\
\hline $\begin{array}{l}\text { Azuma } \\
(1988-1989)\end{array}$ & 19.1 & 46.0 & 21.1 & 11.0 & 1.9 & $\begin{array}{l}100 \% \\
(n=312) \\
100 \% \\
(n=249)\end{array}$ \\
$\begin{array}{l}\text { Azuma } \\
(1998)\end{array}$ & 8.8 & 38.2 & 36.1 & 13.3 & 3.6 & $\begin{array}{l}100 \% \\
(n=251)\end{array}$ \\
$\begin{array}{l}\text { Azuma } \\
(2010-2011)\end{array}$ & 10.4 & 47.4 & 26.7 & 12.8 & 2.8 & $\begin{array}{l}100 \% \\
(n=53)\end{array}$ \\
$\begin{array}{l}\text { Azuma } \\
(2014-2015)\end{array}$ & 5.7 & 49.1 & 43.2 & 0 & 0 & $100 \%$ \\
$\begin{array}{l}\text { Sakernas } \\
2015\end{array}$ & 1.7 & 8.1 & 17.7 & 22.1 & 50.4 & \begin{tabular}{l}
$(n=7,454,767)$ \\
\hline
\end{tabular}
\end{tabular}

Notes. Sakernas 2015 data show Jakarta' population of +10 years. Sources: Field Studies, 1998, 2010-2011, 2014-2015; Sukernas, 2016; Azuma, 2003.

Although Oey-Gardiner (1997, pp. 118-134) pointed out a dramatic improvement in the education level across Indonesia during the Suharto era, becak drivers have never enjoyed such kinds of "fruits of development." If anything, it can be said that further marginalization has increased. The 2015 Sakernas data shows that more than $70 \%$ of Jakarta residents obtained an education level of more than Junior High School (JHS). In contrast, Table 6 shows becak drivers obtained less than 20\%. The data in 2014-2015 must be analyzed carefully due to the limited number of respondents ( 53 respondents), but none completed more than JHS. Therefore, the formal sector offers fewer employment opportunities for becak drivers. The dualistic labour market structure in Jakarta is considered as the threshold to access the formal sector job market (Xue Dong \& Manning, 2017, pp. 15-17; Manning, 1998, pp. 176-179).

\section{Access to the Arable Land}

Table 7 shows the dramatic increase in landless respondents since 1988. The data reveals the scarcity of rural on-farm jobs in home villages. Accessibility to agricultural land has been drastically reduced and as a consequence of this this has been a rise in landless peasants. Azuma (1994; 2006) found, in Indramayu west Java, that five landlords occupied more than half of all arable land in 1991-1992. In 2011, this tendency accelerated. For example, one of my key informants, Haji Kuliwon, had once owned 4.5 ha of rice field and made an additional purchase of 8.0 ha. Mostly it was the fruits of the usurers, but evidence shows that the oligopoly of agricultural land in Indramayu is in progress. It can be said that farmers who do not have access to agricultural land have been flowing into the more accessible profession of becak driving. 
Table 7

Landowning Status of the Respondents (\%)

\begin{tabular}{lllll}
\hline Arable land owned (Ha) & $1988-1989$ & 1998 & $2010-2011$ & $2014-2015$ \\
\hline Landless & 49.1 & 77.7 & 87.3 & 98.1 \\
$0.1-0.5$ & 32.3 & 13.1 & 8.4 & 1.9 \\
$0.5-1.0$ & 15.7 & 5.0 & 3.6 & 0 \\
$1.0-2.0$ & 2.0 & 3.1 & 0.8 & 0 \\
$2.0+$ & 1.9 & 1.1 & 0 & 0 \\
Total & $100 \%$ & $100 \%$ & $100 \%$ & $100 \%$ \\
$(\#)$ & $(303)$ & $(260)$ & $(251)$ & $(53)$ \\
\hline
\end{tabular}

Note. Sources: Field Studies, 1998, 2010-2011, and 2014-2015; Azuma, 2003.

Poor accessibility to arable land resulted in the employment status of the spouse (wife) in Jakarta. Table 8 shows that since 1978, the steady increase in proportions of "Kontrakan" and "own house" is evident. Also, living with spouse had increased within the same house or Kontrakan. As mentioned earlier, accommodation is in a squatter area, but forced evictions in the democratic era (Kegusuran Tanah) have become difficult. In this sense, Jakarta's accessibility is better than that under the New Order. The jobs of their spouses, of course, are in the informal sector. Mostly, casual work, including domestic work, cleaning, laundry and so on do not require higher educational requirements. While becak drivers rented a room or kontrakan in squatter areas, they ask their wives to come to Jakarta for additional income. Such kind of trend shows that both husband and wife are working hard to make a living in Jakarta.

Table 8

Status of Present Accommodation (\%)

\begin{tabular}{|c|c|c|c|c|c|}
\hline $\begin{array}{l}\text { Researcher } \\
\text { Year }\end{array}$ & $\begin{array}{l}\text { Pabel } \\
1978\end{array}$ & $\begin{array}{l}\text { Azuma } \\
1988-1989\end{array}$ & $\begin{array}{l}\text { Azuma } \\
1998\end{array}$ & $\begin{array}{l}\text { Azuma } \\
2010-2011\end{array}$ & $\begin{array}{l}\text { Azuma } \\
2014-2015\end{array}$ \\
\hline Pondok & 74 & 67.3 & 23.6 & 10.4 & 1.90 \\
\hline Kontrakan & 8 & 18.3 & 35.6 & 28.3 & 39.60 \\
\hline Own house & 14 & 5.8 & 5.8 & 26.3 & 17.00 \\
\hline Friends & 3 & 1.9 & 8.7 & 10.0 & 9.40 \\
\hline On becak & n.a. & 4.8 & 26.2 & 15.9 & 45.30 \\
\hline Others & 1 & 1.9 & n.a. & 9.2 & 3.80 \\
\hline $\begin{array}{l}\text { Total } \\
(\#)\end{array}$ & $\begin{array}{l}100 \% \\
(100)\end{array}$ & $\begin{array}{l}100 \% \\
(312)\end{array}$ & $\begin{array}{l}100 \% \\
(275)\end{array}$ & $\begin{array}{l}100 \% \\
(251)\end{array}$ & $\begin{array}{l}100 \% \\
(53)\end{array}$ \\
\hline
\end{tabular}

Note. Sources: Pabel, 1978; Field Studies, 1988-1989, 1998, 2010-2011, and 2014-2015; Azuma, 2003.

Changing patterns of accommodation in Jakarta have influenced migration patterns. Although circular migration is still evident in becak drivers' migration patterns, there is a substantial change in the frequency of visits to their home villages. Table 9 shows that the proportion visiting home every 1-2 weeks declined sharply in 2010-2011 and 2014-2015, whereas the "5-8 weeks" category considerably reduced between 1988-1989 and 1998. In turn, in 2010-2011 and 2014-2015, this category has gained again and constituted more than a quarter and a half in 2014-2015. A major change can be seen in the category of "Others." As mentioned earlier, some of the Kontrak residents brought their families to Jakarta and settled down in shantytowns. They return to their villages once a year for the Islamic holiday of Ramadan. This phenomenon can be explained through economic rationality. The rent for Kontrak cost a minimum of Rp 10,000 a month in 1998 and jumped to a mean of Rp 300,000 in 2014-2015, so those who reside in the Kontrak are likely to reduce their frequency of return. Also, 
"the increasing proportion of dual-earner families" may be another cause of this phenomenon (Qibthiyyah \& Utomo, 2016).

Table 9

The Frequency of Return to Villages in 1988-1989 and 1998, (\%)

\begin{tabular}{lllll}
\hline Frequency/year & $1988-1989$ & 1998 & $2010-2011$ & $2014-2015$ \\
\hline $1-2$ weeks & 24.7 & 21.8 & 8.8 & 1.90 \\
3-4 weeks & 36.9 & 33.1 & 24.3 & 24.50 \\
$5-6$ weeks & 25.5 & 1.8 & 4.8 & 18.90 \\
7-8 weeks & n.a. & 7.3 & 23.5 & 32.10 \\
9-10 weeks & 9.2 & 0.4 & 2.0 & 7.50 \\
$11-12$ weeks & n.a. & 7.3 & 4.4 & 3.80 \\
$13-14$ weeks & 8.2 & 0.7 & 0.8 & n.a. \\
+15 weeks & n.a. & 3.3 & 2.8 & n.a. \\
Others & n.a. & 10.2 & 28.7 & 11.30 \\
Total & $100 \%$ & $100 \%$ & $100 \%$ & $100 \%$ \\
(\#) & $(236)$ & $(236)$ & $(251)$ & $(53)$ \\
\hline
\end{tabular}

Note. Sources: Field Studies, 1988-1989, 1998, 2010-2011, and 2014-2015; Azuma, 2003.

One possible explanation is that the vanishing Pondok system, as mentioned earlier, is deeply related to less frequent home visits. In the 1998 survey, 26.2\% of becak drivers slept on their becak, and understandably they tended to return more frequently than Kontrak residents. On the other hand, the figure shrank by $15.9 \%$ in 2010-2011 (see Table 8). This is because of the substantial decline in the price of becak vehicles, which reduced the risk of stolen or confiscated vehicles.

The other reason for less frequent returns to home villages is increasing accessibility to hand phones (HPs). In 2011-2012, only 30\% of the respondents used HPs but this increased to $70 \%$ in 2014-2015. Most of them purchased affordable second-hand HPs for Rp 100,000-200,000. However, in cases where cash is urgently needed, HPs will be sold after the SIM card is removed. The purpose of using HPs is to call the family in home villages. Also, valuable information on Garokan by SATPOL-PP is brought through HPs. Unfortunately, internet access by HPs (smartphone) was not observed in 2014-2015. Becak drivers did not have new tools like Taxi drivers' Grab or Motorcycle drivers' Gojek ${ }^{11}$. In this context, a clear digital divide was evident.

However, developing digital technology has had a definite impact on the diversification of remittances and this change is significant. For example, Table 10 shows the change in remittance methods over 17 years. In 1998, the category "Carry their own" and "through friends" were common. However, in 2010-2011, this jumped to $11.2 \%$ and reached $66 \%$ in 2014-2015. Remittance agencies using ATM have expanded their business network with a substitute of $3-10 \%$ of commission. For example, becak drivers who sleep on the vehicle can escape the risk of keeping large amounts of money wrapped in plastic in their pockets. In this way, they are not pressured by theft or loss of money. This means that the nationwide development of ATM networks has contributed to improving access to financial services for becak drivers and their families.

\footnotetext{
${ }^{11}$ Gojek was established in 2010 as a motorcycle ride-hailing phone service based in Jakarta. See, https://www.go-jek.com/.
} 
Table 10

How to Send Money to the Village (\%)

\begin{tabular}{llll}
\hline How to send money to the village & 1998 & $2010-2011$ & $2014-2015$ \\
\hline Carry their own & 31.3 & 19.9 & 0 \\
Through a friend & 18.0 & 21.5 & 17.0 \\
Postal/money order & 2.0 & 11.2 & 66.0 \\
Combination & 26.7 & 29.1 & 7.5 \\
Never & 22.0 & 18.3 & 9.5 \\
Total & $100 \%$ & $100 \%$ & $100 \%$ \\
$(\#)$ & $(150)$ & $(251)$ & $(53)$ \\
\hline
\end{tabular}

Note. Sources: Field Studies, 1998, 2010-2011, and 2014-2015; Azuma, 2003.

The total amount of remittances is an important economic indicator. In 1998, the mean remittance

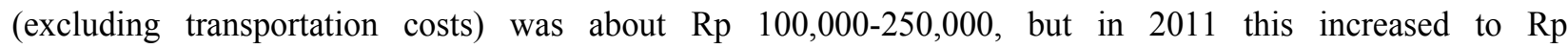
300,000-699,999 and accounted for nearly a half (42\%) and was equivalent to $60 \sim 140 \mathrm{~kg}$ of rice. Considering the rice price is about Rp 5,000 per $\mathrm{kg}$ in rural areas and four families can feed off $1 \mathrm{~kg}$ per day, a considerable amount of money flows from Jakarta to villages. However, De Silva and Sumarto found that "that economic growth in this period benefited households at the top of the expenditure distribution and that a 'trickle down' effect saw the poor receive proportionately fewer benefits than the non-poor" (2014, p. 227).

\section{Conclusion: Accessibility of Security}

This paper has examined the changing nature of becak drivers in Jakarta since 1988 and has presented both the transformation and continuity of their socio-economic conditions in order to investigate the extent to which external forces have affected accessibility over 20 years. Many socioeconomic changes are apparent, such as a growing population of elderly drivers, the total amount of remittances, and provisioning of arable land, especially between 1998 and 2010-2015. In turn, several continuities are also evident. For example, poor educational attainment has hardly changed and the nature of rural-urban circular migration persists (Azuma, 2001b).

In regards to accessibility, as a whole, must be said that universal accessibility to the upper class remains very low: if anything, it is almost impossible. Although a large amount of remittances contribute to urban-rural cash flows, individuals still find it difficult to get out of a subsistence existence. In this sense, the livelihood of becak drivers since the 1980s has not changed. However, it can be said that widespread democracy has allowed for access to expanding human rights, freedom of speech and occupation. This has contributed significantly to the recognition of fundamental human rights such as the protection of private property. Policy towards becak was hard to predict until the new government's policies were formed. Governor Fauji Bowo's (2007-2012) policy towards becak was rather lax due to an insufficient budget for enforcement, ignorance of becak's role, and a careless attitude towards the poor. As such, the fate of becak could still be decided under the new regime (Azuma, 2006).

On September 20, 2012, the Jakarta governor election became a runoff election. Joko Widodo was chosen after defeating the incumbent Governor Fauji Bowo. Widodo's policy was to try to revitalize the traditional market through dialogue rather than crackdown on street vendors in Solo, and he announced the more 
sympathetic policy for socially vulnerable people ${ }^{12}$. However, Jakarta's problem is much more complicated than that of Solo; Jokowi's commitment as the new governor tried to sort out becak transportation problems through a pro-poor policy ${ }^{13}$. The new administration examined the policies from advocacy NGOs on informal sector workers such as the becak and Kakilima. In order to construct a large-scale aggregate store for Kakilima, a dialogue-oriented solution was expected ${ }^{14}$. At one level, it can be said that some achievement was evident. However, Joko Widodo who ran in the 2014 presidential election, became a winner, and his successor Deputy Governor Ahok was promoted to become the new governor taking office in $2015^{15}$. Ahok, as the new governor, took a more authoritarian stance toward policies ${ }^{16}$. SATPOL-PP frequently carried out Garokan, and their frequency has increased such as like under the Sutiyoso era. At the end of February, 2016, a large-scale forced exclusion was implemented, ignoring the wishes of Kali Jodo's residents in order to transform the land into public space $^{17}$.

However, Ahok's effort to restore urban transportation system faced a setback. Since the late 1990s, the number of a motorcycle/taxi named Ojek Motors have increased as a source of revenue for lower-level civil servants and dismissed workers ${ }^{18}$. Becak have been relegated to a more precarious situation between new and old rivals. In the 2010s, there were about 7,000 Bajaj drivers, and Governor Ahok announced that orange colour Bajaj were to be destroyed. He insisted that the two-stroke engine is supposedly the primary source of air pollution, and therefore the orange colour Bajaj had to be successively scrapped. Meanwhile, a new blue Bajai using LPG gas was introduced. At this time, Ojek has already been operating all over the country, becoming a part-time job for young people and lower government officials. They distributed cheap smartphones made in China and started dispatch services through the online application (Gojek). Blue Bajaj also launched a dispatch service called Bajaj App Partner. Furthermore, Ojek actively recruited registrants as a side job for college students and homemakers, and three companies provided the application ${ }^{19}$. Authorizing the dispatch service application resulted in more than one million users and there has now been a movement to effectively use Ojek as a way to alleviate traffic congestion in Jakarta city ${ }^{20}$.

Unfortunately, becak drivers are unable to adjust to the changing urban traffic system in line with the evolution of smartphones and applications. In the beginning, former Governor Ahok did not change his attitude towards becak and did not resort to too many crackdowns, thus they could operate in relative peace. In the mid-2010s, urban traffic dispatch application by smartphone became more common for urban transportation. It may be impossible for older generations to learn new technology such as becak drivers. As such, becak seemed to be disappearing from both Jakarta and around Indonesia.

However, this situation has dramatically changed. The 2017 gubernatorial election campaign was chaotic. Crackdowns on street vendors were occasionally carried out, and Ahok was supposed to be elected again

12 Inilah Kunci Keunggulan Jokowi (This is the key to Jakowi's victory), Kompas, 2012.09.20.

${ }^{13}$ See Joko Widodo's manifest “Jakarta Baru, Pro-Rakyat Miskin, Berbasis Pelayanan dan Partisipasi Warga" (New Jakarta, Pro-Poor based on Community Service and Participation), 15 September 2012.

${ }_{14}$ Inilah Strategi Pemenangan Jokowi-Basuki (This is Jokowi-Basuki's winning strategy), Kompas, 2012.09.21.

15 Ratusan Tukang Becak Demo dan Antarkan "Surat Galau” kepada Ahok (Hundreds of becak drivers Demonstrate and Deliver "Disturbing Letters" to Ahok, Kompas, 28 January 2016.

${ }^{16}$ Tribune Jakarta, 2015.12.20.

${ }^{17}$ See for example, "Masih Berani Narik Becak di Jakarta? Ini Akibatnya"(Still Willing to Ride Becak in Jakarta? This is the result, http://www.tribunnews.com/metropolitan/2015/12/20/masih-berani-narik-becak-di-jakarta-ini-akibatnya.

18 Suara Karya, 18 Feb. 1998.

19 Jakarta Shimbun, August 22 and 28, 2015.

20 Jakarta Shinbun, September 19, 2015. 
despite opposition from the urban poor. In contrast, the former Education Minister Anies Buswaden who advocated "development without pain/fear" emerged as a competing horse and was victorious over governor Ahok. The new Governor Anies Buswaden decided to abolish the Becca Prohibition Law (Perda 2007, Nomor 8 ) on January 15 , 2018, as promised. It acknowledged that only certain tourist areas, such as Mampang, and flooded areas of north Jakarta's business area, were to be authorized. When residents need to bring large quantities of stuff from the local market and carry children to school, residents are desperate for becak vehicles. Moreover, becak drivers decided not to operate on the main arterial roads and congested areas as in the past (Hadiz, 2017).

A more interesting phenomenon is the negative opinion of Jakarta citizens at the Kompas Website ${ }^{21}$. Contributors often insensitively write that becak make life difficult for the residents living in the submerged areas of the northern Jakarta during the rainy season. For example, permitting becak to operate is a step backwards as the modern subway is coming into operation. There are also comments that there will be a return to a 'Stone Age.' As such, there is a culture of viewing becak as a symbol of Indonesian backwardness that has not substantially changed over the decades. Thus, it can be said that Jakarta citizens have little understanding of the nature of becak operations and areas. Of the 169 comments written up to February 5, 2018, only two people supported this policy. ${ }^{22}$

There are also comments that many Jakarta citizens have never seen becak. This suggests a geographical bias in operation districts and a lack of information may be generating such prejudices. This is because as Kompas (2018.1.25) has noted, about 220 becak are in operation in north Jakarta, and also about $50^{23}$ to 100 becak were brought from Indramayu to Jakarta. ${ }^{24}$

The new governor issued an Ordinance (Nomor 878, Tahun 2018), and there was no exclusion here. ${ }^{25}$ Becak vehicle registration began in February 2018 in collaboration between city authorities and the UPC following an influx from surrounding cities. The method used now is to stick a registration card on authorized vehicle from local authorities (see Figure 4). With this, it became possible to operate safely without fear of confiscation. $^{26}$

Governor Anies was one of the leading candidates in the presidential election scheduled for April 2019. The Jakarta UPC demonstrated in front of the state government building to complete the term of office five years instead of seven months to Governor Anies. For various reasons Governor Anies denied running for the presidential election in July 2018 and becak drivers responded with joy. Hence, it can be said that their

\footnotetext{
${ }^{21}$ See for example, “Penghapusan Operasional Becak di Jakarta, dari 1936 hingga Kini...”, Development of Becak Elimination in Jakarta, from 1936 to $\quad$ present (https://megapolitan.kompas.com/read/2018/01/15/11212121/penghapusan-operasional-becak-di-jakarta-dari-1936-hingga-kini?pa ge=all.Penulis $\quad$ Kontributor $\quad$ Jakarta, $\quad$ David Purbahttps://megapolitan.kompas.com/read/2018/01/15/11212121/penghapusan-operasional-becak-di-jakarta-dari-1936-hingga-ki ni?page=all

${ }_{22}$ "Ketika Becak Berusaha Masuk Jakarta ". (When Becak Try to Enter Jakarta) http://megapolitan.kompas.com/read/2018/01/15/07584671/gubernur-anies-akan-buat-rute-khusus-untuk-becak.

${ }_{23}$ "Cerita Tukang Becak di Indramayu yang Tak Tergoda Pindah ke Jakarta" (The Story of becak drivers in Indramayu that is not moving to Jakarta), Kompas, 30/01/2018.

24 "Cerita tukang becak di Indramayu yang tak tergoda pindah ke Jakarta" (The story of becak drivers in Indramayu not tempted to move to Jakarta) http: //regional.ko, http://regional.kompas.com/read/2018/01/30/06300031/.

25 “Massa Aksi di Depan Balai Kota Minta Anies Tidak Nyapres" (Demonstators in front of the City Hall asks Anies not to run President), https://megapolitan.kompas.com/read/2018/07/23/. https://megapolitan.kompas.com/read/2018/07/23/.

26 "Saya Deg-degan Belum Ada Stiker Becak, Takut Ditarik Kamtib" (I was Scared, there are no becak stickers, afraid to be confiscated by Kamtib) Kompas, 13/03/2018, https://megapolitan.kompas.com/read/2018/03/13/18531301/.
} 
operation will be safeguarded until 2022 which is Governor Anies's remaining term. ${ }^{27}$ The situation is more lax than before because there is a low likelihood of confiscation. Harsh confiscations are unlikely to be tolerated because of an increasing awareness of human rights, and support from NGOs under ongoing democratization in Indonesia. However, an uncertain future and inconsistent policy towards becak made becak drivers continues to induce insecurity. In this context, accessibility to security remains unchanged over the past 20 years (Azuma, 2006).

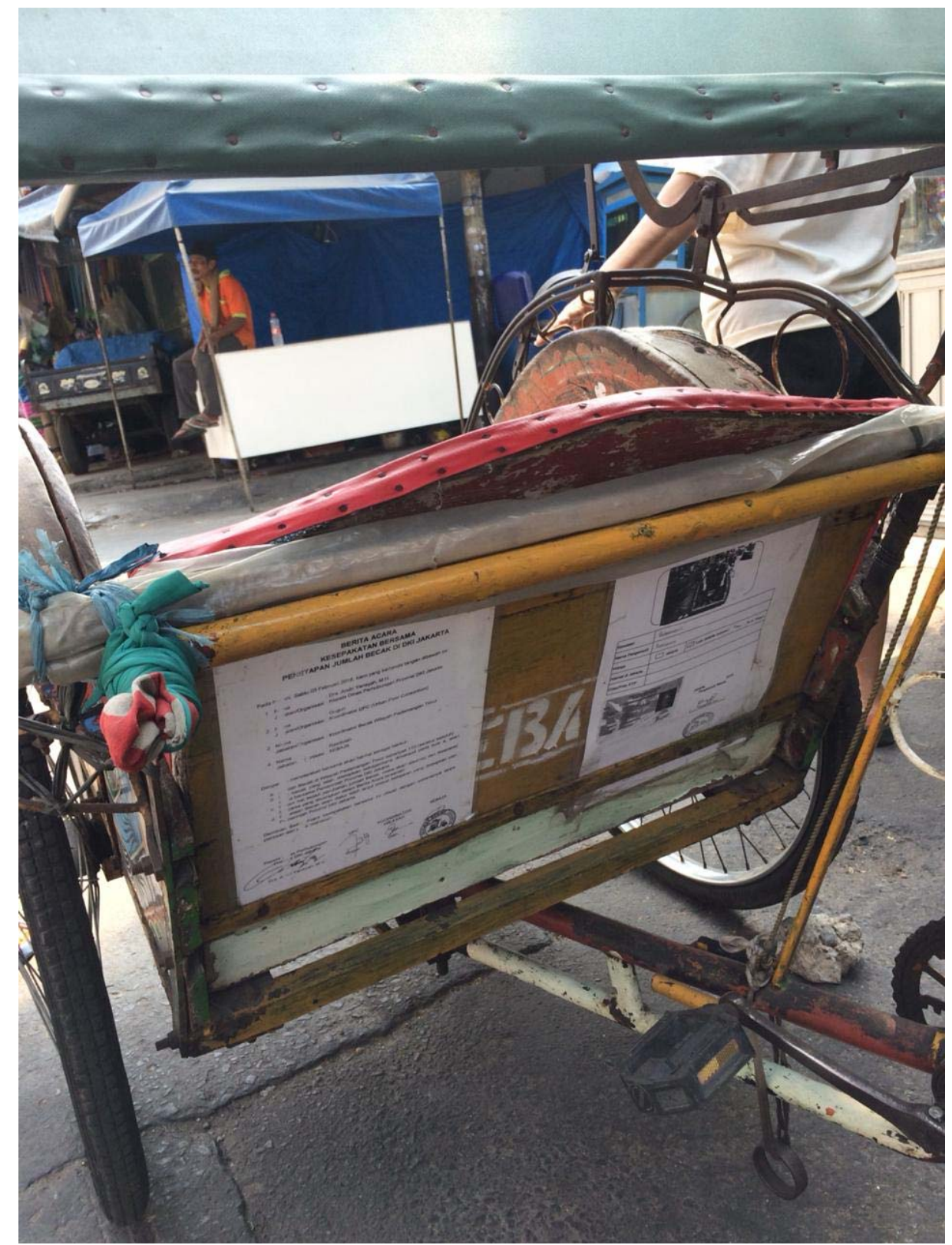

Figure 4. Becak vehicle's registration sticker (tentative).

\footnotetext{
27 “Serikat Becak: Saat Pilih Pak Anies, Kan Tujuannya 5 Tahun, Bukan 8 Bulan” (Becak Union: When Choosing Anies fo the Governor , The Goals Are 5 Years, Not 8 Months, Kompas, 23/07/2018, https://megapolitan.kompas.com/read/2018/07/23/14333351/serikat-becak-saat-pilih-pak-anies-kan-tujuannya-5-tahun-bukan-8-bulan.
} 


\section{References}

Anderson, B. (2009). Post-revolutionary Djakarta: Accessible City. Proceedings from The $2^{\text {nd }}$ Jakarta Seminar and the $41^{\text {st }}$ Research Institute for Humanity and Nature seminar series on Thursday, Nov. 12, 2009.

Anderson, B. (2010). ヤシがら椀の外へ (Yashi Kara Wan no Soto he) 加藤剛訳 2010 NTT出版 (Journey out of the coconut shell) Translated from English by Kato Tsuyoshi, NTT Publishing, 2010. (English version published 2016 as A Life Beyond Boundaries: A Memoir. London: Verso.

Azuma, Y. (1994). Beca drivers in Jakarta, a study of rural-urban circular migrants from Indramayu, West Java and Tegal, Central Java (Unpublished Ph.D. Thesis, Flinders University of South Australia, Adelaide).

Azuma, Y. (2000). Socio-economic changes among beca drivers in Jakarta, 1988-1998 (2000). Labour and Management in Development, 1(6), 3-31.

Azuma, Y. (2001a). Abang Becak, Sekejam-kejamnya Ibu tiri Masih lebih kejam Ibu kota (Becak drivers in Jakarta; Jakarta is more cruel than a step mother). Indonesia: Pusutaka Sinar Harapan.

Azuma, Y. (2001b). Political economy of becak drivers in Jakarta: A historical review (2001). Monash University, Centre of Southeast Asian Studies Working Paper No. 111.

Azuma, Y. (2003). Urban peasants: Beca drivers in Jakarta. Jakarta Indonesia: Sinar Harapan Press.

Azuma, Y. (2006). ジャカル夕のベチや引き達一国家にょる暴力から民衆間の暴力へ—「ジヤカルターアジアメガシテ イの光と影」(Jakaruta no Bechahikitachi: Kokka ni Yoru bouryoku kara Minshukan no Boryoku he “Jakaruka Ajia Megashitti no Hikari to Kage). Becak drivers in Jakarta: from state-sponsored violence to interfaith violence- "The Light and Shadow of Jakarta-Asia Megacity” Bensei Published, pp. 128-140.

De Silva, I., \& Sumarto, S. (2014). Does economic growth really benefit the poor? Income distribution dynamics and pro-poor growth in Indonesia. Bulletin of Indonesian Economic Studies, 50(2), 227-242.

DKI \& Sekernas. (2016). Survei Angkatan Kerja Nasional (SAKERNAS).

DKI. (1978). Becak, Hasil Penelitian Pengemudi Becak Di DKI Jakarta. Jakarta: DKI.

DKI. (2007). Satuan Polisi Pamong Praja (SATPOL PP). Jakarta: Provinsi DKI.

Garschagen, M., Surtiari, G., \& Harb, M. (2018). Is Jakarta's new flood risk reduction strategy transformational? Retrieved from www.mdpi.com/journal/sustainability

Hadiz, R. (2017). Indonesia's year of democratic setbacks: Towards a new phase of deepening illiberalism? (BIES) Bulletin of Indonesian Economic Studies, 53(3), 261-278.

Jellinek, L. (1991). The wheel of fortune, the history of a poor community in Jakarta. Sydney: Allen and Unwin.

Jones, G., Rangkuti, H., Utomo, A., \& McDonald, P. (2016). Migration, ethnicity, and the educational gradient in the Jakarta Mega-Urban Region: A spatial analysis. Bulletin of Indonesian Economic Studies, 52(1), 55-76.

Kantor Statistik DKI. (2007). Jakarta Dalam Angka 2008. Jakarta: DKI.

Manning, C. (1998). Indonesian labour in transition. An East Asian success story? Cambridge: Cambridge University Press.

Oey-Gardiner, M. (1997). Educational developments, achievements and challenges. In G. Jones, \& T. Hull (Eds.), Indonesia assessment, population and human resources (pp.135-166). Singapore: ANU/Institute of Southeast Asian Studies.

Pabel, M. (1978). Respons Pengemudi Becak Terhadap Peraturan Daerah Bebas Becak, Studi Kasus Pengemudi Becak di Jakarta Timur DKI (BA Thesis, UI, Jakarta).

Qibthiyyah, R., \& Utomo, A. (2016). Family matters: Demographic change and social spending in Indonesia. Bulletin of Indonesian Economic Studies, 52(2), 133-159.

Winayantia, L., \& Lang, H. (2004). Provision of urban services in an informal settlement: A case study of Kampung Penas Tanggul, Jakarta. Habitat International, 28, 41-65.

World Bank. (2007). World development report agriculture for development. Washington DC: The World Bank.

Xue Dong, S., \& Manning, M. (2017). Labour-market developments at a time of heightened uncertainty. Bulletin of Indonesian Economic Studies, 53(1), 1-25.

Yayasan Tenaga Kerja Indonesia (YTKI). (1987). Becak drivers and scavengers in Jakarta. Jakarta: Mimeo, YTKI. 